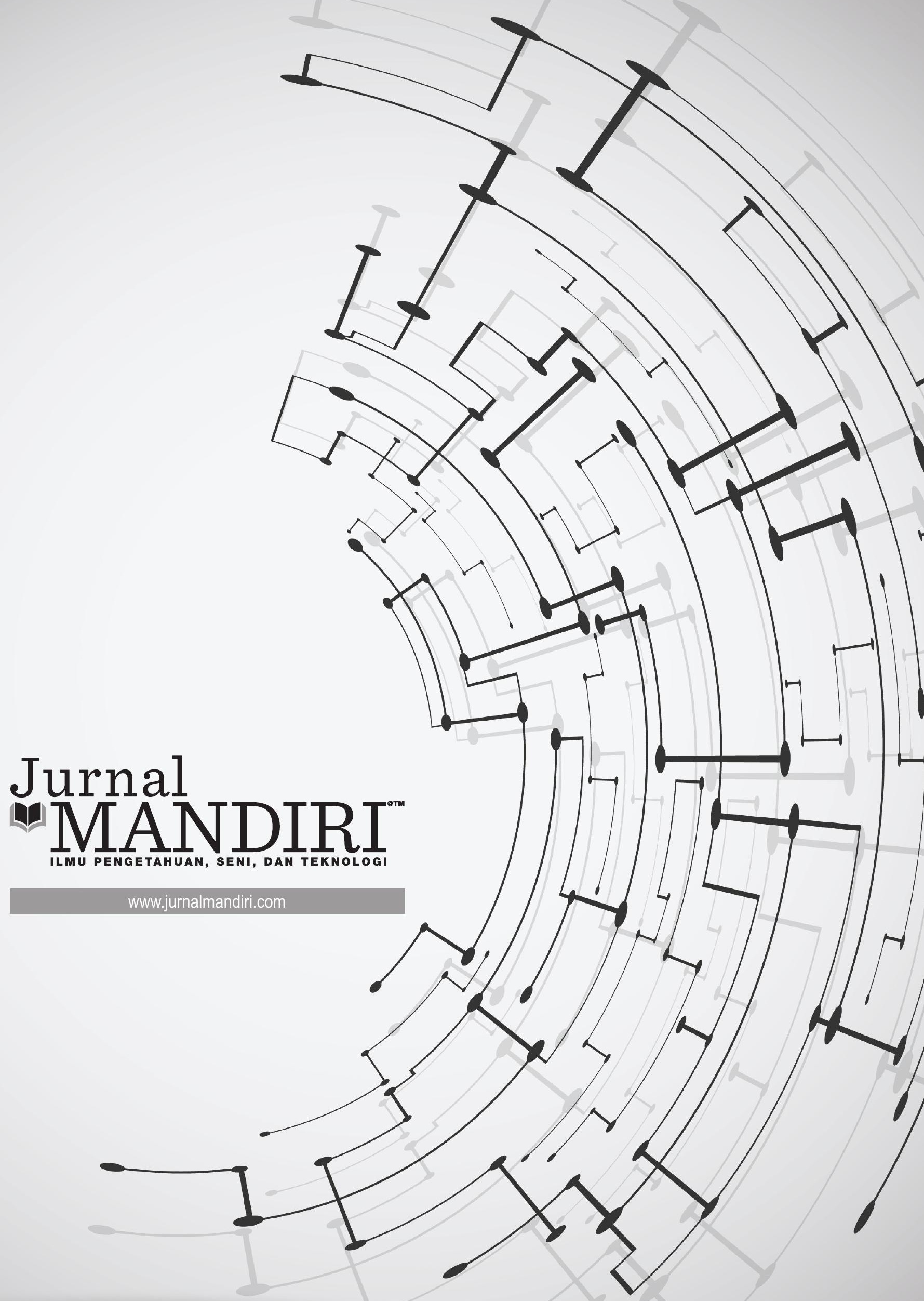


ISSN : 2580-3220, E-ISSN : 2580-4588

J. Mandiri., Vol. 4, No. 1, Juni 2020 (26 - 37)

(C)2018 Lembaga Kajian Demokrasi

dan Pemberdayaan Masyarakat (LKD-PM)

DOI : https://doi.org/10.33753/mandiri.v4i1.106

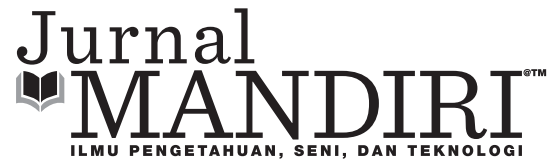

\title{
Pengaruh Kualitas Pelayanan dan Harga Terhadap Kepuasan Pelanggan Pada Pengguna Jasa Service di Dealer Honda Wahana Ciputat
}

\author{
Putri Nilam Kencana \\ Fakultas Ekonomi, Universitas Pamulang \\ dosen01877@unpam.ac.id \\ Kasdiyo \\ Fakultas Ekonomi, Universitas Pamulang \\ kazdiyo@gmail.com
}

\begin{abstract}
Abstrak
Penelitian ini bertujuan adalah untuk mengetahui Pengaruh Kualitas Pelayanan dan Harga Terhadap Kepuasan Pelanggan Pada Pengguna Jasa Service di Dealer Honda Wahana Ciputat. Metode penelitian yang digunakan adalah kuantitatif dengan eksplanasi deskriptif. Teknik sampel yang digunakan adalah Accidental Sampling dengan jumlah responden sebanyak 100. Adapun metode analisis yang digunakan adalah uji validitas, uji reliabilitas, uji koefisien korelasi, uji regresi linear berganda, uji koefisien determinasi dan uji hipotesis penelitian. Dari hasil penelitian diketahui bahwa kualitas pelayanan mempunyai nilai koefisien regresi sebesar 0.489, nilai thitung lebih besar dari ttabel (8.742 > 1.985) dan nilai signifikan lebih kecil dari 0,05 $(0.000<0,05)$. Artinya $\mathrm{H}_{a}$ diterima dan $\mathrm{H}_{0}$ ditolak. Menurut perkiraan jika kualitas pelayanan meningkat sebesar 1 satuan maka kepuasan pelanggan akan mengalami peningkatan sebesar 0.516. Hasil analisis menunjukkan harga

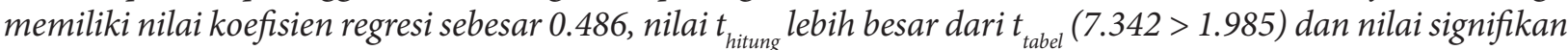
lebih kecil dari 0,05 $(0.000<0,05)$. Artinya $\mathrm{H}_{a}$ diterima dan $\mathrm{H}_{0}$ ditolak. Dengan tafsiran, jika harga meningkat sebesar 1 satuan maka kepuasan pelanggan akan meningkat sebesar 0.486. Hasil analisis menunjukkan bahwa kualitas pelayanan dan harga secara simultan berpengaruh signifikan terhadap kepuasan pelanggan dengan nilai kontribusi sebesar 0.712, nilai $F_{\text {hitung }}$ sebesar $123.278>3.09$, nilai signifikansi sebesar $0.000<0.05$. Artinya kualitas pelayanan dan harga secara simultan memiliki kemampuan menjelaskan variabel kepuasan pelanggan sebesar 71,2\% sedangkan sisanya sebesar 18,8\% dijelaskan oleh variabel lain di luar penelitian ini.
\end{abstract}

Kata Kunci : Kualitas Pelayanan, Harga, Kepuasan Pelanggan

\begin{abstract}
The purpose of this study was to determine the Effect of Service Quality and Price on Customer Satisfaction in Service Users at the Wahana Ciputat Honda Dealer. The research method used is quantitative with descriptive explanation. The sample technique used is Accidental Sampling with 100 respondents. The analytical method used is validity test, reliability test, correlation coefficient test, multiple linear regression test, coefficient of determination test and test the research hypothesis. The results of the analysis show the quality of service has a regression coefficient value of 0.489 , the value of $t_{\text {count }}$ is greater than $t_{\text {table }}(8,742>1,985)$ and the significant value is smaller than $0.05(0,000<0.05)$. This means that $H_{a}$ is accepted and $H_{0}$ is rejected. With interpretation, if service quality increases by 1 unit, customer satisfaction will increase by 0.516 . The analysis shows that the price has a regression coefficient of 0.486 , the value of $t$ is greater than $t_{\text {table }}(7,342>1,985)$ and the significant value is smaller than $0.05(0,000<0.05)$. This means that $H_{a}$ is accepted and $H_{0}$ is rejected. With interpretation, if the price increases by 1 unit, customer satisfaction will increase by 0.486 . The results of the analysis show that
\end{abstract}


service quality and price simultaneously have a significant effect on customer satisfaction with a contribution value of 0.712 , a $F_{\text {count }}$ value of $123.278>3.09$, a significance value of $0.000<0.05$. This means that service quality and price simultaneously have the ability to explain variable customer satisfaction by $71.2 \%$ while the remaining $18.8 \%$ is explained by other variables outside this study.

Keywords : Service Quality, Price, Customer Satisfaction

\section{PENDAHULUAN}

\section{Latar Belakang}

Tingginya tingkat persaingan dalam menual produk mengindikasikan bahwa salah satu faktor penting untuk sebuah perusahaan yaitu kepuasan konsumen pada produk yang dipasarkan sehingga daya kompetitif lebih tinggi dan membantu mencapai keberhasilan yang diharapkan oleh perusahaan perusahaan. Oliver (2017:31), menyatakan bahwa kepuasan pelanggan adalah satu satu elemen penting dalam pemasaran dan berperan secara signifikan dipasar.

Menurut data web resmi masing-masing dari sumbernya tercatat jumlah unit cabang dealer yang berada di Tangerang Selatan, Honda memiliki dealer resmi sekitar 10 dealer penjualan \& servis, sedangkan dealer Yamaha sendiri ada 18 dealer penjualan \& servis dan suzuki motor ada 5 dealer penjualan \& servis. Angka ini tentunya menjadi faktor bagi perusahaan untuk menyadari betapa pentingnya strategi pemasaran yang akan di tetapkan untuk melawan kompetitornya (Yamaha).

Berdasarkan lokasi pemasaran, dapat dilihat bahwa lokasi Dealer Honda Wahana cabang Ciputat strategis daripada yang lainnya. Bisa dilihat dari lokasinya yang berada di pinggir jalan raya Ciputat. Lalu dilihat juga berdasarkan fasilitas tempat parkir, dapat dikatakan area yang dimiliki Dealer Honda Wahana cabang Ciputat sangat kondusif, dan cukup strategis hingga mudah dijangkau. Namun beberapa tahun belakangan ini, pengunjung atau pembeli kendaraan di Dealer Honda Wahana cabang Ciputat diketahui menurun berdasarkan data yang diperoleh dari Departemen Penjualan di bawah ini.

Tabel 1. Data Penjualan Dealer PT Wahanaartha Ritelindo Cabang Ciputat

\begin{tabular}{|c|c|c|c|c|} 
No & Tahun & $\begin{array}{c}\text { Penjualan } \\
\text { Dalam Unit }\end{array}$ & $\begin{array}{c}\text { Pertumbuhan } \\
(\%)\end{array}$ & Keterangan \\
\hline 1 & $\begin{array}{c}2018 \text { (Januari/Kuartal I s.d } \\
\text { September/Kuartal III) }\end{array}$ & 78 & $-61 \%$ & Turun \\
\hline
\end{tabular}

\begin{tabular}{|l|l|l|l|l|}
\hline 2 & 2017 & 198 & $-2 \%$ & Turun \\
\hline 3 & 2016 & 203 & $12 \%$ & Naik \\
\hline 4 & 2015 & 182 & $-9 \%$ & Turun \\
\hline 5 & 2014 & 200 & $-7 \%$ & Turun \\
\hline 6 & 2013 & 214 & - & - \\
\hline \multicolumn{4}{|c|}{ Sumber: Dealer Honda Wahana cabang Ciputat (2018) } \\
\hline
\end{tabular}

Menurut tabel 1, dalam periode enam tahun belakangan ada tren penurunan penjualan pada Dealer Honda Wahana Cabang Ciputat. Faktanya adalah pada 2018 (data Kuartal I Kuartal III) menurun secara signifikan dimana bagian penjualan hanya mampu menjual 78 unit motor yang menunjukkan sebesar $-61 \%$ terjadi penurunan (menurut dari tahun 2017), sedangkan di periode 2017 hanya mencapai -2\% pertumbuhan, 2016 mengalami pertumbuhan sebesar $12 \%$, dan pertumbuhan sebesar $-9 \%$ pada tahun 2015 serta pertumbuhannya sebesar -7\% pada tahun 2014. Dari data-data ini dapat dilihat bahwa terjadi penurunan penjualan dan pada enam tahun belakangan terjadi stagnasi, di mana penjualan tidak meningkat secara drastis. Selama beberapa tahun berikutnya juga tidak ada perubahan yang berarti pada penjualan. Maka dapat disimpulkan bahwa ada kendala atau permasalahan dalam penjualan yang dialami oleh Dealer Honda Wahana Cabang Ciputat.

\begin{tabular}{|c|c|c|c|}
\hline \multicolumn{4}{|c|}{ Tabel 2. Jumlah Komplain } \\
Tahun & $\begin{array}{c}\text { Jumlah Pelanggan } \\
\text { (Orang) }\end{array}$ & $\begin{array}{c}\text { Jumlah Komplain } \\
\text { (Orang) }\end{array}$ & $\%$ \\
\hline 2013 & 214 & 23 & $11 \%$ \\
\hline 2014 & 200 & 48 & $24 \%$ \\
\hline 2015 & 182 & 40 & $22 \%$ \\
\hline 2016 & 203 & 39 & $19 \%$ \\
\hline 2017 & 198 & 34 & $17 \%$ \\
\hline \multicolumn{2}{|c|}{ Sumber: Dealer Honda Wahana Cabang Ciputat (2018) } \\
\hline
\end{tabular}

Berdasarkan data di atas diketahui jumlah komplain pelanggan Dealer Honda Wahana Cabang Ciputat. Adanya komplain menjelaskan 
ketidakpuasan konsumen atau pelanggan terhadap perusahaan. Data di atas memperlihatkan bahwa jumlah pelanggan atau konsumen yang komplain terhadap Dealer Honda Wahana Cabang Ciputat pada tahun 2013 sebanyak 23 komplain, pada tahun 2014 sebanyak 48 komplain, 40 komplain pada tahun 2015, 39 komplain pada tahun 2016 dan 34 komplain pada tahun 2017.

Berdasarkan uraian diatas maka penulis tertarik mengadakan penelitian dengan mengambil judul "Pengaruh Kualitas Pelayanan Dan Harga Terhadap Kepuasan Pelanggan Pada Pengguna Jasa Service Di Dealer Honda Wahana Ciputat”.

\section{Pembatasan Masalah}

Berdasarkan uraian latar belakang tersebut maka dibuatlah pembatasan masalah agar penelitian ini menjadi lebih terfokus dan tujuan dari penelitian bisa tercapai dan hipotesis bisa dijawab Penelitian terhadap kualitas pelayanan berdasarkan pada aspek, tangible (kasat mata), reliability (keandalan), responsiveness (daya tanggap), assurance (Jaminan), dan empathy (empati), penelitian pada harga berdasarkan aspek, terjangkau, kewajaran, metode pembayaran, kesesuaian harga dengan manfaat. Penelitian terhadap kepuasan pelanggan berdasarkan pada aspek, kesesuaian harapan, minat berkunjung kembali, kesediaan merekomendasikan. Penelitian dilakukan di Dealer Honda Wahana Ciputat yang beralamat di Jl. Ir. H. Juanda No. 43, Cempaka Putih, Ciputat, Tangerang Selatan, dan dengan waktu pelaksanaan penelitian dilakukan selama 3 bulan, mulai dari bulan September 2019 hingga November 2019.

\section{METODE}

Penelitian ini dilakukan dengan metode penelitian kuantitatif yang diolah dengan aplikasi statistic. Dilaksanakan di Dealer Honda Wahana Ciputat yang berlokasi di Jl. Ir. H. Juanda, No. 43, Cempaka Putih, Ciputat, Tangerang Selatan. Untuk menentukan sampel penelitian maka digunakan teknik Accidental Sampling. Teknik insidentalsamplinginimenurutpendapatSugiyono (2012:122) adalah metode yang menentukan sampel menurut kebetulan. Dimana objek atau narasumber penelitian tidak direncanakan lebih dahulu namun bertemu begitu saja secara kebetulan dan dianggap layak untuk memberikan data terkait penelitian. Pelanggan pada pengguna jasa service di Dealer Honda Wahana Ciputat yang sedang melakukan service dipilih menjadi sampel penelitian. Berdasarkan data dari Dealer Honda Wahana Cabang Ciputat pada tahun 2018 tercatat ada 133 pelanggan. Selanjutnya data ini yang digunakan oleh penulis dalam menentukan jumlah sampel. Untuk menentukan jumlah sampel paling sedikit maka digunakan pedoman penentuan sampel. Penelitian ini kemudian memilih menerapkan rumus dari Slovin dalam Umar Husein (2012:108) yaitu:

$$
n=\frac{\mathrm{N}}{1+\mathrm{N}(e)^{2}}
$$

\section{Keterangan:}

$$
\begin{array}{ll}
\mathrm{n} & =\text { Jumlah sampel } \\
\mathrm{N} & =\text { Jumlah populasi } \\
\mathrm{e}^{2} & =\frac{133}{1+\left(133 \times 5 \%^{2}\right)} \\
& \frac{133}{1+(133 \times 0.0025)} \\
\frac{133}{1.33}=99,81 \text { digenapkan menjadi } 100
\end{array}
$$

Menurut hasil perhitungan tersebut maka dibutuhkan 100 orang sebagai sampel penelitian. Kepada sampel penelitian tersebut akan diserahkan kuesioner untuk diisi per individu.

\section{HASIL dan PEMBAHASAN \\ Hasil}

\section{Kualitas Pelayanan}

Kotler dan Armstrong (2014:18) menjelaskan bahwa jasa merupakan kegiatan atau tindakan yang tidak berwujud namun bisa ditawarkan oleh suatu pihak kepada pihak lain namun tidak serta merta mempengaruhi kepemilikan pada suatu hal yang relevan pada produk materi ataupun tidak. 
Hurriyati (2010:28) mengutip pendapat Zeithamal dan Bitner menjelaskan bahwa jasa diinterpretasikan sebagai kegaiatan ekonomi yang menghasilkan selain produk dalam makna fisik, pada prinsipnya tidak mempunyai bentuk dan bisa dihasilkan secara bersama-sama dan mendapatkan nilai tambah.

\section{Harga}

Harga yang ditetapkan untuk suatu produk ataupun layanan adalah faktor yang menentukan untuk permintaan pasar. Posisi kompetisi antara satu perusahaan lainnya dapat dipengaruhi oleh harga serta dapat memberikan pengaruh pada marketshare-nya. Program pemasaran perusahaan juga dapat dipengaruhi oleh harga yang ditetapkan atas suatu produk atau jasa maka dari itu harga adalah bagian dari marketing mix yang bisa memberikan profik untuk perusahaan.

Harga adalah penentu untuk biaya jasa dan pelayanan yang kita butuhkan. (Swastha dan Irawan, 2014:147). Dapat dikatakan juga bahwa harga merupakan nilai uang yang harus dibayar oleh pembeli dan akan diterima oleh penjual.

Dharmesta dan Irawan (2015:11) menjelaskan harga merupakan nilai uang yang diperlukan dalam mendapatkan produk dan juga jasa yang ditawarkan.

\section{Kepuasan Pelanggan}

Kepuasan pelanggan menurut pendapat Kotler dan Keller (2012:78), rasa senang ataupun kecewa dari seorang pembeli setelah membeli barang dan melakukan penilaian dan perbandingan pada hasil dan juga harapannya. Kepuasan merupakan aspek terkait pengalaman dan perbandingan yang kemudian membentuk penilaian bisa memuaskan kebutuhan secara mental, rohani tidak saja karena merasakan kenyamanan namun juga sesuai dengan bayangan dan juga harapan. Kepuasan seorang pembeli bukanlah emosi namun wujud dari penilaian dan juga emosi.

Tjiptono (2012:146), menjelaskan bahwa kepuasan konsumen adalah penilaian setelah membeli produk yang sebelumnya dilakukan lebih dulu pertimbangan dan pilihan untuk menghasilkan outcome yang sesuai atau melebihi harapan pembeli, sementara rasa tidak puas muncul jika hasil tidak sesuai dengan ekspektasi pembeli.

Menurut defenisi-defenisi yang telah dijelaskan tersebut maka kesimpulan yang bisa ditarik yaitu kepuasan konsumen merupakan hasil yang sesuai dengan harapan. Pembeli akan membuat estimasi atau perhitungan mengenai produk atau jasa yang akan diperolehnya sebelum membelinya. Sementara itu kinerja yang dirasakan merupakan persepsi konsumen pada produk atau jasa yang ia terima.

\section{Hasil Analisis Kuesioner \\ Karakteristik Responden}

Untuk penelitian responden menggunakan 100 orang konsumen yang datang ke Dealer Honda Wahana. Kepada 100 orang responden tersebut diberikan kuesioer secara langsung. Rangkuman informasi karakteristik responden penelitian dapat dilihat dibawah ini:

\begin{tabular}{|c|c|c|c|}
\hline No & Keterangan & Jumlah & Persentase \\
\hline 1 & Laki-laki & 58 & $58 \%$ \\
\hline 2 & Perempuan & 42 & $42 \%$ \\
\hline & Total & 100 & $100 \%$ \\
\hline \multicolumn{4}{|c|}{ Sumber: Data Primer Diolah (2018) } \\
\hline
\end{tabular}

Dapat dilihat berdasarkan tabel diatas yaitu ada 58 orang atau $58 \%$ dan responden adalah lakilaki dan ada 42 orang atau $42 \%$ adalah perempuan. Oleh karena itu jumlah sampel minimum yang digunakan sudah sesuai yakni 100 responden.

\begin{tabular}{|c|c|c|c|}
\hline \multicolumn{4}{|c|}{ Tabel 4. Karakteristik Responden Berdasarkan Usia } \\
\hline No & Keterangan & Jumlah & Persentase \\
\hline 1 & $15-25$ tahun & 23 & $23 \%$ \\
\hline 2 & $26-35$ tahun & 36 & $36 \%$ \\
\hline 3 & $36-45$ tahun & 22 & $22 \%$ \\
\hline 4 & $\geqslant 46$ tahun & 19 & $19 \%$ \\
\hline & Total & 100 & $100 \%$ \\
\hline
\end{tabular}

Dapat dilihat berdasarkan tabel diatas yaitu ada 36 orang atau $36 \%$, responden berusia di antara 26-35 tahun, kemudian 23 orang atau 23\% responden berusia 15-25 tahun, ada 22 orang atau $22 \%$ dan responden berusia 36-45 tahun, dan 
sama dengan di atas 46 tahun sebanyak 19 orang atau $19 \%$. Artinya bahwa pelanggan di Dealer Honda Wahana mempunyai latar belakang yang bervariasi baik dari usia, dan juga kalangan.

\begin{tabular}{|c|c|c|c|}
\hline \multicolumn{4}{|c|}{ Tabel 5. Data Karakteristik Responden Berdasarkan Status } \\
\hline No & Keterangan & Jumlah & Persentase \\
\hline 1 & Pelajar & 15 & $15 \%$ \\
\hline 2 & Pegawai / Karyawan & 34 & $34 \%$ \\
\hline 3 & Wirausaha & 48 & $48 \%$ \\
\hline 4 & Ibu Rumah Tangga & 3 & $3 \%$ \\
\hline & Total & 100 & $100 \%$ \\
\hline \multicolumn{4}{|c|}{ Sumber: Data Primer Diolah (2018) } \\
\hline
\end{tabular}

Menurut tabel di atas, pelanggan Dealer Honda Wahana 15 orang merupakan pelajar, dari sebanyak 34 orang merupakan pegawai/karyawan, dari kalangan wirausaha sebanyak 48 orang dan dari kalangan ibu rumah tangga sebanyak 3 orang.

\section{Deskripsi Data Hasil Kuesioner}

"Pada bagian ini akan dilakukan analisis deskriptif data kuesioner yang sudah disebarkan pada 100 responden. Dengan rincian seperti pada tabel 6 dibawah ini":

\begin{tabular}{|c|c|c|c|}
\hline No & Kriteria & Disingkat & Skor Nilai \\
\hline 1 & Sangat Baik & SB & $4,20-5,00$ \\
\hline 2 & Baik & B & $3,40-4,19$ \\
\hline 3 & Cukup/Kurang Baik & $\mathrm{CB} / \mathrm{KB}$ & $1,60-3,39$ \\
\hline 4 & Rendah & $\mathrm{R}$ & $1,80-2,59$ \\
\hline 5 & Sangat Rendah & SR & $1,00-1,79$ \\
\hline \multicolumn{4}{|c|}{ Sumber: Istijanto (2014:85) } \\
\hline
\end{tabular}

\begin{tabular}{|c|c|c|c|c|c|c|c|c|c|}
\hline \multicolumn{10}{|c|}{ Tabel 4. Hasil Uji Deskriptif Angka Indeks } \\
\hline \multirow{2}{*}{ No } & \multirow{2}{*}{ Pernyataan } & SS & s & $\mathbf{R}$ & TS & STS & \multirow{2}{*}{ Total } & \multirow{2}{*}{ Rata-rata } & \multirow{2}{*}{ Kategori } \\
\hline & & 5 & 4 & 3 & 2 & 1 & & & \\
\hline \multicolumn{10}{|c|}{ Indikator Kasat Mata } \\
\hline 1 & $\begin{array}{l}\text { Tampilan Gedung Dealer Honda Wahana } \\
\text { bagus }\end{array}$ & 200 & 168 & 36 & 10 & 1 & 415 & 4.15 & Baik \\
\hline 2 & $\begin{array}{l}\text { Desain ruangan Dealer Honda Wahana } \\
\text { menarik }\end{array}$ & 205 & 164 & 36 & 12 & 0 & 417 & 4.17 & Baik \\
\hline \multicolumn{10}{|c|}{ Indikator Keandalan } \\
\hline 3 & $\begin{array}{l}\text { Suasana di Dealer Honda Wahana } \\
\text { membuat pelanggan nyaman/betah } \\
\text { (ruangan ber-AC dan tidak gaduh) }\end{array}$ & 205 & 168 & 33 & 12 & 0 & 418 & 4.18 & Baik \\
\hline 4 & $\begin{array}{l}\text { Fasilitas di Dealer Honda Wahana lengkap } \\
\text { (TV, Internet, dll) }\end{array}$ & 195 & 176 & 36 & 10 & 0 & 417 & 4.17 & Baik \\
\hline \multicolumn{10}{|c|}{ Indikator Daya Tanggap } \\
\hline 5 & $\begin{array}{l}\text { Karyawan Dealer Honda Wahana tanggap } \\
\text { terhadap kebutuhan pelanggan }\end{array}$ & 195 & 160 & 51 & 4 & 2 & 412 & 4.12 & Baik \\
\hline 6 & $\begin{array}{l}\text { Karyawan Dealer Honda Wahana cepat } \\
\text { dalam memperbaiki kendaraan }\end{array}$ & 75 & 260 & 54 & 4 & 0 & 393 & 3.93 & Baik \\
\hline \multicolumn{10}{|c|}{ Indikator Jaminan } \\
\hline 7 & $\begin{array}{l}\text { Karyawan Dealer Honda Wahana bersikap } \\
\text { ramah kepada pelanggan }\end{array}$ & 65 & 248 & 66 & 6 & 0 & 385 & 3.85 & Baik \\
\hline 8 & $\begin{array}{l}\text { Karyawan Dealer Honda Wahana bersikap } \\
\text { sopan kepada pelanggan }\end{array}$ & 125 & 228 & 48 & 4 & 0 & 405 & 4.05 & Baik \\
\hline \multicolumn{10}{|c|}{ Indikator Jaminan } \\
\hline 9 & $\begin{array}{l}\text { Karyawan Dealer Honda Wahana perhatian } \\
\text { terhadap kebutuhan pelanggan }\end{array}$ & 75 & 232 & 69 & 6 & 1 & 383 & 3.83 & Baik \\
\hline 10 & $\begin{array}{l}\text { Karyawan Dealer Honda Wahana peduli } \\
\text { terhadap kebutuhan pelanggan }\end{array}$ & 200 & 172 & 36 & 10 & 0 & 418 & 4.18 & Baik \\
\hline \multirow{2}{*}{\multicolumn{2}{|c|}{ Kualitas pelayanan }} & 154 & 198 & 47 & 8 & 0 & 406 & 4.06 & Baik \\
\hline & & & & & & Keter & ata c & $\begin{array}{l}\text { Der: Data } \\
\text { tal / jum }\end{array}$ & - diolah (2018 \\
\hline
\end{tabular}

Berdasarkan "tabel di atas diketahui kualitas pelayanan Dealer Honda Wahana dipersepsikan Baik dengan rata-rata jawaban sebesar 4,06. Adapun kualitas pelayanan Dealer Honda Wahana yang dipersepsikan paling rendah adalah indi- kator empati yakni kuesioner No. 9 dengan ratarata jawaban sebesar" 3,83 yang berbunyi "Karyawan Dealer Honda Wahana perhatian terhadap kebutuhan pelanggan". 


\begin{tabular}{|c|c|c|c|c|c|c|c|c|c|}
\hline 8 & $\begin{array}{l}\text { Saya bersedia menyarankan kepada } \\
\text { teman-teman untuk service di Dealer } \\
\text { Honda Wahana }\end{array}$ & 170 & 160 & 75 & 2 & 0 & 407 & 4.07 & Baik \\
\hline 9 & $\begin{array}{l}\text { Saya Bersedia mereferensikan Dealer } \\
\text { Honda Wahana kepada teman-teman }\end{array}$ & 175 & 188 & 51 & 2 & 0 & 416 & 4.16 & Baik \\
\hline 10 & $\begin{array}{l}\text { Saya bersedia memberikan testimoni } \\
\text { (pengalaman pribadi) baik tentang kualitas } \\
\text { service di Dealer Honda Wahana }\end{array}$ & 185 & 144 & 75 & 4 & 0 & 408 & 4.08 & Baik \\
\hline & Kepuasan Pelanggan & 176 & 170 & 61 & 3 & 1 & 410 & 4.10 & Baik \\
\hline
\end{tabular}

Berdasarkan tabel di“atas diketahui kepuasan pelanggan Dealer Honda Wahana secara umum dipersepsikan Baik dengan rata-rata jawaban sebesar 4,10. Adapun kepuasan pelanggan Dealer Honda Wahana yang dipersepsikan paling rendah adalah indikator" Minat berkunjung kembali yakni kuesioner No. 4 dengan rata-rata jawaban sebesar 3,97 yang berbunyi "Dealer Honda Wahana memiliki citra yang baik".

\section{Pembahasan}

\section{Uji Validitas}

"Uji validitas untuk penelitian ini adalah dengan nilai $r_{\text {tabel }} 0,195$ sebagai pembanding (Sugiyono, 2012:524). Maka dari itu apabila suatu kuesioner memiliki nilai R product Moment lebih besar dari $\mathrm{r}_{\text {tabel }}$ maka dapat disimpulkan kuesioner tersebut valid. Dengan penggunaan software SPSS 22 maka hasil uji validitas yang diperoleh adalah sebagai berikut:"

\begin{tabular}{|c|c|c|c|c|}
\hline No & Kriteria & $\begin{array}{c}\text { R } \\
\text { Product } \\
\text { Moment }\end{array}$ & $r_{\text {tabel }}$ & Kesimpulan \\
\hline 1 & $\begin{array}{l}\text { Tampilan Gedung Dealer Honda } \\
\text { Wahana bagus }\end{array}$ & 0,722 & 0,195 & Valid \\
\hline 2 & $\begin{array}{l}\text { Desain ruangan Dealer Honda } \\
\text { Wahana menarik }\end{array}$ & 0,830 & 0,195 & Valid \\
\hline 3 & $\begin{array}{l}\text { Suasana di Dealer Honda } \\
\text { Wahana membuat pelanggan } \\
\text { nyaman/betah (ruangan ber-AC } \\
\text { dan tidak gaduh) }\end{array}$ & 0,824 & 0,195 & Valid \\
\hline 4 & $\begin{array}{l}\text { Fasilitas di Dealer Honda } \\
\text { Wahana lengkap (TV, Internet, } \\
\text { dll) }\end{array}$ & 0,886 & 0,195 & Valid \\
\hline 5 & $\begin{array}{l}\text { Karyawan Dealer Honda } \\
\text { Wahana tanggap terhadap } \\
\text { kebutuhan pelanggan }\end{array}$ & 0,919 & 0,195 & Valid \\
\hline 6 & $\begin{array}{l}\text { Karyawan Dealer Honda } \\
\text { Wahana cepat dalam } \\
\text { memperbaiki kendaraan }\end{array}$ & 0,713 & 0,195 & Valid \\
\hline 7 & $\begin{array}{l}\text { Karyawan Dealer Honda } \\
\text { Wahana bersikap ramah } \\
\text { kepada pelanggan }\end{array}$ & 0,705 & 0,195 & Valid \\
\hline
\end{tabular}

\begin{tabular}{|c|l|c|c|c|}
\hline 8 & $\begin{array}{l}\text { Karyawan Dealer Honda } \\
\text { Wahana bersikap sopan kepada } \\
\text { pelanggan }\end{array}$ & 0,497 & 0,195 & Valid \\
\hline 9 & $\begin{array}{l}\text { Karyawan Dealer Honda } \\
\text { Wahana perhatian terhadap } \\
\text { kebutuhan pelanggan }\end{array}$ & 0,737 & 0,195 & Valid \\
\hline 10 & $\begin{array}{l}\text { Karyawan Dealer Honda } \\
\text { Wahana peduli terhadap } \\
\text { kebutuhan pelanggan }\end{array}$ & 0,801 & 0,195 & Valid \\
\hline \multicolumn{4}{|c|}{ Sumber: Data diolah SPSS 22, 2018 } \\
\hline
\end{tabular}

Menurut tabel di atas, dapat dilihat bahwa keseluruhan pernyataan (kuesioner) variabel kualitas pelayanan mempunyai nilai $\mathrm{R}$ Products Moment lebih besar dari $\mathrm{r}_{\text {tabel }}$ dengan demikian kesimpulan yang bisa ditarik adalah kuesioner variabel kualitas pelayanan yang diajukan dalam penelitian ini adalah valid.

\begin{tabular}{|c|c|c|c|c|}
\hline \multicolumn{5}{|c|}{ Tabel 11. Uji Validitas Variabel Harga ( $\left.X_{2}\right)$} \\
\hline No & Kriteria & $\begin{array}{c}\mathbf{R} \\
\text { Product } \\
\text { Moment }\end{array}$ & $r_{\text {tabel }}$ & Kesimpulan \\
\hline 1 & $\begin{array}{l}\text { Harga service di Dealer Honda } \\
\text { Wahana terjangkau }\end{array}$ & 0,652 & 0,195 & Valid \\
\hline 2 & $\begin{array}{l}\text { Harga sucu cadang di Dealer } \\
\text { Honda Wahana standar }\end{array}$ & 0,684 & 0,195 & Valid \\
\hline 3 & $\begin{array}{l}\text { Harga service di Dealer } \\
\text { Honda Wahana sesuai dengan } \\
\text { kemampuan pelanggan }\end{array}$ & 0,532 & 0,195 & Valid \\
\hline 4 & $\begin{array}{l}\text { Harga servicedi Dealer Honda } \\
\text { Wahana adalah harga pada } \\
\text { umumnya (pasaran) }\end{array}$ & 0,673 & 0,195 & Valid \\
\hline 5 & $\begin{array}{l}\text { Dealer Honda Wahana sering } \\
\text { mengadakan promo yaitu } \\
\text { diskon (potongan harga) } \\
\text { terhadap pembelian suku } \\
\text { cadang tertentu }\end{array}$ & 0,707 & 0,195 & Valid \\
\hline 6 & $\begin{array}{l}\text { Metode pembayaran di Dealer } \\
\text { Honda Wahana dapat dilakukan } \\
\text { secara tunai }\end{array}$ & 0,519 & 0,195 & Valid \\
\hline 7 & $\begin{array}{l}\text { Metode pembayaran di Dealer } \\
\text { Honda Wahana dapat dilakukan } \\
\text { secara Debet }\end{array}$ & 0,679 & 0,195 & Valid \\
\hline 8 & $\begin{array}{l}\text { Harga service di Dealer } \\
\text { Honda Wahana sesuai dengan } \\
\text { manfaatnya }\end{array}$ & 0,415 & 0,195 & Valid \\
\hline 9 & $\begin{array}{l}\text { Harga suku cadang di Dealer } \\
\text { Honda Wahana sesuai dengan } \\
\text { kualitasnya }\end{array}$ & 0,694 & 0,195 & Valid \\
\hline 10 & $\begin{array}{l}\text { Harga motor di Dealer Honda } \\
\text { Wahana sesuai dengan tipenya }\end{array}$ & 0,464 & 0,195 & Valid \\
\hline
\end{tabular}


Menurut tabel di atas, dapat dilihat dari seluru pernyataan (kuesioner) variabel harga mempunyai nilai R Products Moment lebih besar dari $\mathrm{r}_{\text {tabel }}$ kesimpulan yang dapat ditarik yaitu kuesioner variabel harga yang diajukan dalam penelitian ini adalah valid.

Tabel 12. Uji Validitas Variabel Kepuasan pelanggan (Y)

\begin{tabular}{|c|c|c|c|c|}
\hline No & Kriteria & $\begin{array}{l}\mathbf{R} \\
\text { Product } \\
\text { Moment }\end{array}$ & $r_{\text {tabel }}$ & Kesimpulan \\
\hline 1 & $\begin{array}{l}\text { Service di Dealer Honda } \\
\text { Wahana hasilnya sesuai } \\
\text { dengan keinginan pelanggan }\end{array}$ & 0,677 & 0,195 & Valid \\
\hline 2 & $\begin{array}{l}\text { Membeli suku cadang di Dealer } \\
\text { Honda Wahana kualitasnya } \\
\text { terjamin }\end{array}$ & 0,641 & 0,195 & Valid \\
\hline 3 & $\begin{array}{l}\text { Membeli motor di Dealer } \\
\text { Honda Wahana banyak pilihan }\end{array}$ & 0,681 & 0,195 & Valid \\
\hline 4 & $\begin{array}{l}\text { Dealer Honda Wahana memiliki } \\
\text { citra yang baik }\end{array}$ & 0,729 & 0,195 & Valid \\
\hline 5 & $\begin{array}{l}\text { Saya merasa puas jika service } \\
\text { di Dealer Honda Wahana }\end{array}$ & 0,643 & 0,195 & Valid \\
\hline 6 & $\begin{array}{l}\text { Saya puas dengan pelayanan di } \\
\text { Dealer Honda Wahana }\end{array}$ & 0,643 & 0,195 & Valid \\
\hline 7 & $\begin{array}{l}\text { Saya bersedia mengajak } \\
\text { keluarga untuk service di } \\
\text { Dealer Honda Wahana }\end{array}$ & 0,732 & 0,195 & Valid \\
\hline 8 & $\begin{array}{l}\text { Saya bersedia menyarankan } \\
\text { kepada teman-teman untuk } \\
\text { service di Dealer Honda } \\
\text { Wahana }\end{array}$ & 0,806 & 0,195 & Valid \\
\hline 9 & $\begin{array}{l}\text { Saya Bersedia mereferensikan } \\
\text { Dealer Honda Wahana kepada } \\
\text { teman-teman }\end{array}$ & 0,745 & 0,195 & Valid \\
\hline 10 & $\begin{array}{l}\text { Saya bersedia memberikan } \\
\text { testimoni (pengalaman pribadi) } \\
\text { baik tentang kualitas service di } \\
\text { Dealer Honda Wahana }\end{array}$ & 0,700 & 0,195 & Valid \\
\hline \multicolumn{5}{|c|}{ Sumber: Data diolah SPSS 22, 2018} \\
\hline
\end{tabular}

Menurut "tabel di atas, dapat dilihat bahwa semua pernyataan (kuesioner) variabel kepuasan pelanggan memiliki nilai R Products Moment lebih besar dari $\mathrm{r}_{\text {tabel }}$ kesimpulan dari hasil tersebut adalah" kuesioner variabel kepuasan pelanggan yang diajukan dalam penelitian ini adalah valid.

\section{Uji Reliabilitas}

Uji "reliabilitas yang digunakan pada penelitian ini yaitu kriteria minimum cronbach alpha 0,60 (Sugiyono, 2012:190). Artinya jika suatu variabel memiliki nilai cronbach alpha sama dengan lebih besar $(\geq)$ dari 0,60 maka kesimpulannya adalah kuesioner variabel tersebut sudah reliabel." Berikut hasil output SPSS 22 uji reliabilitas dalam penelitian ini:

\begin{tabular}{c|l|c|c|c|}
\hline \multicolumn{5}{c|}{ Tabel 13. Uji Reliabilitas } \\
No & \multicolumn{1}{|c|}{ Variabel } & $\begin{array}{c}\text { Nilai } \\
\text { Cronbach } \\
\text { Alpha }\end{array}$ & $\begin{array}{c}\text { Kriteria } \\
\text { Minimun }\end{array}$ & Kesimpulan \\
\hline 1 & Kualitas Pelayanan & 0,921 & 0,60 & Reliabel \\
\hline 2 & Harga & 0,807 & 0,60 & Reliabel \\
\hline 3 & Kepuasan Pelanggan & 0,885 & 0,60 & Reliabel \\
\hline \multicolumn{4}{|c|}{ Sumber: Data diolah SPSS 22, 2018 } \\
\hline
\end{tabular}

Menurut "tabel yang telah dicantumkan, maka bisa dilihat bahwa semua variabel (kualitas pelayanan, harga dan kepuasan pelanggan) mempunyai nilai cronbach alpha lebih besar (>) dari 0,60 dengan demikian kesimpulan yang bisa ditarik adalah kuesioner" variabel dalam penelitian ini adalah reliabel dan bisa lanjut untuk analisis berikutnya (analisis Regresi).

\section{Uji Asumsi Klasik \\ Uji Normalitas}

\begin{tabular}{|c|c|c|}
\hline \multicolumn{3}{|c|}{ Tabel 14. Uji Normalitas } \\
\hline \multicolumn{3}{|c|}{ One-Sample Kolmogorov-Smirnov Test } \\
\hline & & $\begin{array}{l}\text { Unstandardized } \\
\text { Residual }\end{array}$ \\
\hline $\mathrm{N}$ & & 100 \\
\hline \multirow[t]{2}{*}{ Normal Parameters ${ }^{\mathrm{a}, \mathrm{b}}$} & Mean &, 0000000 \\
\hline & Std. Deviation & 2,28356288 \\
\hline \multirow[t]{3}{*}{ Most Extreme Differences } & Absolute & .106 \\
\hline & Positive & .106 \\
\hline & Negative &,- 077 \\
\hline Kolmogorov-Smirnov Z & & 1.047 \\
\hline Asymp. Sig. (2-tailed) & & .741 \\
\hline \multicolumn{3}{|c|}{$\begin{array}{l}\text { a. Test distribution is Normal. } \\
\text { b. Calculated from data. }\end{array}$} \\
\hline
\end{tabular}

Berdasarkan "tabel di atas, diketahui bahwa nilai Asymp.Sig. (2-tailed) sebesar 0.741 lebih besar dari kriteria minimum 0.05 (Ghozali, 2016:102), maka dapat disimpulkan bahwa semua variabel dalam penelitian ini" telah memenuhi kriteria normalitas.

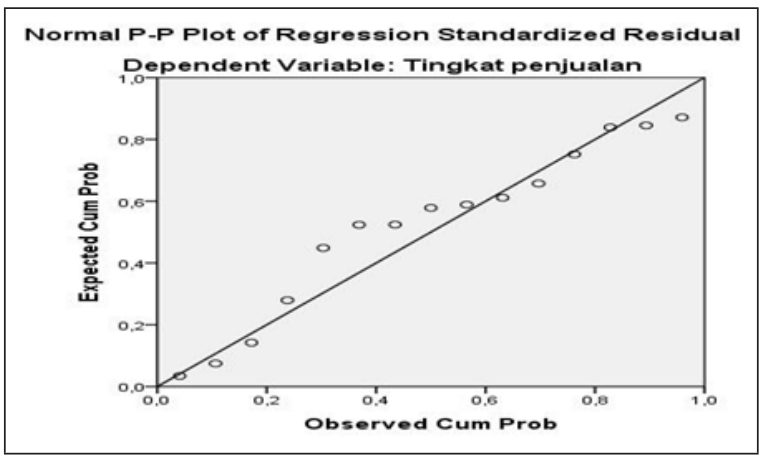

Gambar 1. Uji Normalitas 


\section{Uji Multikolinearitas}

\begin{tabular}{|c|c|c|c|c|}
\hline \multicolumn{5}{|c|}{ Tabel 15. Uji Multikolinearitas } \\
\hline & \multirow{2}{*}{ Model } & \multirow{2}{*}{ Sig. } & \multicolumn{2}{|c|}{ Collinearity Statistics } \\
\hline & & & Tolerance & VIF \\
\hline \multirow[t]{3}{*}{1} & (Constant) & .462 & & \\
\hline & Kualitas Pelayanan & .000 & .775 & 1.290 \\
\hline & Harga & .000 & .775 & 1.290 \\
\hline
\end{tabular}

Dari hasil olah data di atas,bisa dilhat bahwa kualitas pelayanan memiliki nilai VIF sebesar 1.290 dan nilai VIF harga sebesar 1.290, di mana kedua nilai VIF variabel tersebut lebih kecil dari 10 (kriteria uji multikolinearitas, Ghozali; 2016:112), kesimpulan yang dapat ditarik yaitu bahwa data dalam penelitian ini tidak menunjukkan adanya multikolinearitas.

\section{Uji Heteroskedastisitas}

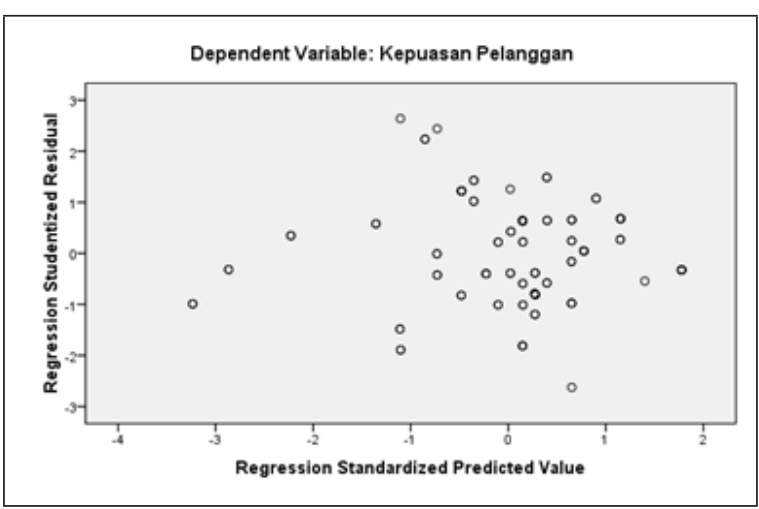

Gambar 2. Uji Heteroskedastisitas

Berdasarkan gambar di atas, diketahui jika data menyebar secara merata baik pada ruang positif maupun pada ruang negatif. Kesimpulan yang bisa ditarik adalah apabila data dalam penelitian ini telah memenuhi asumsi heteroskedastisitas.

\section{Uji Koefisien Korelasi}

Sugiyono (2012:2100) mengemukakan pedoman penilaian uji koefisien korelasi sebagai berikut:

\begin{tabular}{|c|c|}
\hline \multicolumn{2}{|c|}{ Tabel 16. Pedoman Penilaian Uji Koefisien Korelasi } \\
\hline Interval Koefisien & Tingkat Hubungan \\
\hline $0,00-0,199$ & Sangat rendah \\
\hline $2,00-0,399$ & Rendah \\
\hline $4,00-0,599$ & Sedang \\
\hline $6,00-0,799$ & Kuat \\
\hline
\end{tabular}

\begin{tabular}{|c|c|}
\hline $8,00-1,000$ & Sangat Kuat \\
\hline \multicolumn{2}{|c|}{ Sumber: Sugiyono (2012:2100) } \\
\hline
\end{tabular}

Berikut adalah hasil pengujian koefisien korelasi diberikan menurut output SPSS 22 sebagai berikut:

\begin{tabular}{|c|c|c|c|c|}
\hline \multicolumn{5}{|c|}{ Tabel 17. Uji Koefisien Korelasi } \\
\hline \multicolumn{5}{|c|}{ Correlations } \\
\hline & & $\begin{array}{c}\text { Kualitas } \\
\text { Pelayanan }\end{array}$ & Harga & $\begin{array}{l}\text { Kepuasan } \\
\text { Pelanggan }\end{array}$ \\
\hline \multirow{3}{*}{$\begin{array}{l}\text { Kualitas } \\
\text { Pelayanan }\end{array}$} & Pearson Correlation & 1 & $.474^{* *}$ & $.749^{* *}$ \\
\hline & Sig. (2-tailed) & & .000 & .000 \\
\hline & $\mathrm{N}$ & 100 & 100 & 100 \\
\hline \multirow{3}{*}{ Harga } & Pearson Correlation & $.474^{* *}$ & 1 & $.704^{* *}$ \\
\hline & Sig. (2-tailed) & .000 & & .000 \\
\hline & $\mathrm{N}$ & 100 & 100 & 100 \\
\hline \multirow{3}{*}{$\begin{array}{l}\text { Kepuasan } \\
\text { Pelanggan }\end{array}$} & Pearson Correlation & $.749^{* *}$ & $.704^{* *}$ & 1 \\
\hline & Sig. (2-tailed) & .000 & .000 & \\
\hline & $\mathrm{N}$ & 100 & 100 & 100 \\
\hline \multicolumn{5}{|c|}{ Sumber: Hasil Olah Data SPSS 22, 2018} \\
\hline
\end{tabular}

Berdasarkan tabel di atas, bisa disimpulkan bahwa nilai korelasi variabel kualitas pelayanan dengan kepuasan pelanggan sebesar 0.749 masuk pada kategori "kuat". Sedangkan nilai korelasi antara harga dengan kepuasan pelanggan sebesar 0.704 masuk pada kategori kuat. Sehingga bisa dikatakan juga bahwa ada hubungan yang signifikan antara variabel kualitas pelayanandan harga dengan kepuasan pelanggan.

\section{Uji Regresi Linear}

\begin{tabular}{|c|c|c|c|c|c|c|}
\hline \multicolumn{7}{|c|}{ Tabel 18. Uji Regresi Linear } \\
\hline \multicolumn{7}{|c|}{ Coefficients ${ }^{a}$} \\
\hline \multirow{2}{*}{\multicolumn{2}{|c|}{ Model }} & \multicolumn{2}{|c|}{$\begin{array}{l}\text { Unstandardized } \\
\text { Coefficients }\end{array}$} & \multirow{2}{*}{$\begin{array}{c}\begin{array}{c}\text { Standardized } \\
\text { Coefficients }\end{array} \\
\text { Beta }\end{array}$} & \multirow{2}{*}{$t$} & \multirow{2}{*}{ Sig. } \\
\hline & & B & $\begin{array}{l}\text { Std. } \\
\text { Error }\end{array}$ & & & \\
\hline \multirow{3}{*}{1} & (Constant) & 2.024 & 2.741 & & .739 & .462 \\
\hline & $\begin{array}{l}\text { Kualitas } \\
\text { Pelayanan }\end{array}$ & .489 & .056 & .536 & 8.742 & .000 \\
\hline & Harga & .486 & .066 & .450 & 7.342 & .000 \\
\hline \multicolumn{7}{|c|}{ a. Dependent Variable: Kepuasan pelanggan } \\
\hline \multicolumn{7}{|c|}{ Sumber: Hasil Olah Data SPSS 22, 2018} \\
\hline
\end{tabular}

Berdasarkan "hasil olah data di atas, maka dapat dikemukakan persamaan regresi linear berganda sebagai berikut: $=\mathrm{a}+\beta^{1} \mathrm{X}^{1}+\beta^{2} \mathrm{X}^{2}$

$$
Y=2.024+0.489 X^{1}+0.486 X^{2}
$$


Keterangan:

- $\mathrm{Y}=$ Kepuasan pelanggan

- $\quad \mathrm{a}$ (konstanta $)=2.024$

- b (koefisien regresi) = Koefisien Kualitas pelayanan sebesar 0.489

- $\quad$ Koefisien Harga sebesar 0.486

Kesimpulan yang bisa diambil dari persamaan di atas terkait Nilai konstanta sebesar 2.024 dapat diinterprtasikan bahwa walaupun meskipun tidak terdapat pengaruh dari variabel kualitas pelayanan dan harga, kepuasan pelanggan terhadap Dealer Honda Wahana tetap terbentuk sebesar 2.024. Kualitas pelayanan menunjukkan adanya pengaruh yang signifikan terhadap kepuasan pelanggan. Indikatornya adalah nilai koefisien regresi sebesar 0.489 , nilai $t_{\text {hitung }}$ sebesar 8.742 lebih besar dari $1.985(8.742>1.985)$ dan nilai signifikansi sebesar 0,000 lebih kecil dari $0,05(0.000<0.05)$. Harga terbukti mempunyai pengaruh positif signifikan terhadap kepuasan pelanggan dengan indikator nilai koefisien regresi sebesar 0.486 , nilai $t_{\text {hitung }}$ sebesar 7.342 lebih besar dari $1.985(7.342>1.985)$ dan nilai signifikansi sebesar 0,000 lebih kecil dari 0,05 $(0.000<0.05)$.

\section{Uji Signifikansi Pengaruh Parsial (uji t)}

Dalam uji signifikan (uji t) maka terlebih dahulu ditentukan $\mathrm{T}_{\text {tabel }}$ sebagai pembanding, dengan cara:

$$
\begin{aligned}
& \mathrm{Df}=\mathrm{n}-\mathrm{k} \\
& \text { nilai sig }=0,05
\end{aligned}
$$

keterangan:

$\mathrm{n}$ = jumlah sampel (sampel dalam penelitian ini sebanyak 100)

$\mathrm{k}=$ jumlah variabel bebas dan terikat (3)

Df $=100-3=97$

Oleh karena itu berdasarkan penjelasan Sugiyoni (2012:523) tentang $\mathrm{T}_{\text {tabel }}$, oleh karena itu nilai $\mathrm{T}_{\text {tabel }}$ yang diperoleh adalah ebesar 1.985. Dibawah ini disertakan hasil uji t penelitian.

\section{Pengaruh Kualitas Pelayanan}

\begin{tabular}{|c|c|c|c|c|c|c|}
\hline \multicolumn{7}{|c|}{ Tabel 19. Uji Parsial (Uji t) } \\
\hline \multicolumn{7}{|c|}{ Coefficients ${ }^{\mathrm{a}}$} \\
\hline \multirow{2}{*}{\multicolumn{2}{|c|}{ Model }} & \multicolumn{2}{|c|}{$\begin{array}{l}\text { Unstandardized } \\
\text { Coefficients }\end{array}$} & \multirow{2}{*}{$\begin{array}{c}\text { Standardized } \\
\text { Coefficients } \\
\text { Beta }\end{array}$} & \multirow{2}{*}{$t$} & \multirow{2}{*}{ Sig. } \\
\hline & & B & $\begin{array}{c}\text { Std. } \\
\text { Error }\end{array}$ & & & \\
\hline \multirow[b]{2}{*}{1} & (Constant) & 2.024 & 2.741 & & .739 & .462 \\
\hline & $\begin{array}{l}\text { Kualitas } \\
\text { Pelayanan }\end{array}$ & .489 & .056 & .536 & 8.742 & .000 \\
\hline \multicolumn{7}{|c|}{ Sumber: Hasil Olah Data SPSS 22, 2018} \\
\hline
\end{tabular}

Terhadap Kepuasan Pelanggan

Berdasarkan tabel tersebut dapat dikemukakan sebagai berikut:

- Persamaan Regresi Y $=2.024+0.489$

(kualitas pelayanan)

- $\mathrm{T}_{\text {hitung }}=8.742$

- Nilai Signifikan $=0.000$

Berdasarkan keterangan tersebut di atas, maka dapat dikemukakan penjelasan Bahwa nilai konstanta sebesar 2,024"mempunyai arti, bahwa walau tidak ditemukan adanya pengaruh dari variabel kualitas pelayanan, kepuasan pelanggan tetap terbentuk sebesar 2,024. Variabel Kualitas pelayanan mempunyai" nilai $\mathrm{t}_{\text {hitung }}$ lebih besar dari $\mathrm{t}_{\text {tabel }}(8.742>1.985)$ dan nilai signifikan lebih kecil dari $0,05(0.000<0,05)$. Artinya $\mathrm{H}_{\mathrm{a}}$ diterima dan $\mathrm{H}_{0}$ ditolak. Koefisien regresi sebesar 0.489 , artinya kualitas pelayanan memiliki nilai pengaruh positif dan signifikan terhadap kepuasan pelanggan sebesar 0.489. Dengan tafsiran, jika kualitas pelayanan meningkat sebesar 1 satuan maka kepuasan pelanggan akan meningkat sebesar 0.489 .

\section{Pengaruh Harga Terhadap Kepuasan pelanggan}

\begin{tabular}{|c|c|c|c|c|c|c|}
\hline \multicolumn{7}{|c|}{ Coefficients $^{a}$} \\
\hline \multirow{2}{*}{\multicolumn{2}{|c|}{ Model }} & \multicolumn{2}{|c|}{$\begin{array}{l}\text { Unstandardized } \\
\text { Coefficients }\end{array}$} & \multirow{2}{*}{$\begin{array}{c}\begin{array}{c}\text { Standardized } \\
\text { Coefficients }\end{array} \\
\text { Beta }\end{array}$} & \multirow{2}{*}{$t$} & \multirow{2}{*}{ Sig. } \\
\hline & & B & $\begin{array}{l}\text { Std. } \\
\text { Error }\end{array}$ & & & \\
\hline \multirow{2}{*}{1} & (Constant) & 2.024 & 2.741 & & .739 & .462 \\
\hline & Harga & .486 & .066 & .450 & 7.342 & .000 \\
\hline
\end{tabular}

Tabel 20. Uji Parsial (Uji t)

Berdasarkan tabel tersebut dapat dikemukakan sebagai berikut: 
- $\quad$ Persamaan Regresi $\mathrm{Y}=2,024+0.486 \mathrm{X} 2$

- $\mathrm{T}_{\text {hitung }}=7.342$

- Nilai Signifikan $=0.000$

Berdasarkan keterangan tersebut di atas, maka dapat dikemukakan penjelasan Bahwa nilai konstanta sebesar 2,024 memiliki arti, meskipun tidak ada pengaruh dari variabel harga, kepuasan pelanggan tetap terbentuk sebesar 2,024. Variabel Harga mempunyai nilai $\mathrm{t}_{\text {hitung }}$ lebih besar dari $\mathrm{t}_{\text {tabel }}$ (7.342>1.985) dan nilai signifikan lebih kecil dari $0,05(0.000<0,05)$. Artinya $\mathrm{H}_{\mathrm{a}}$ diterima dan $\mathrm{H}_{0}$ ditolak. Koefisien regresi sebesar 0.486 , artinya harga mempunyai nilai pengaruh positif dan signifikan terhadap kepuasan pelanggan sebesar 0.486. Dengan tafsiran, jika harga meningkat sebesar 1 satuan maka kepuasan pelanggan akan mengalami peningkatan sebanyak 0.486 .

\section{Uji Simultan (uji f)}

\begin{tabular}{|c|c|c|c|c|c|c|}
\hline \multicolumn{7}{|c|}{ Tabel 21. Uji simultan (Uji F) } \\
\hline \multicolumn{7}{|c|}{ ANOVA $^{b}$} \\
\hline \multicolumn{2}{|c|}{ Model } & $\begin{array}{l}\text { Sum of } \\
\text { Squares }\end{array}$ & Df & $\begin{array}{l}\text { Mean } \\
\text { Square }\end{array}$ & $\mathbf{F}$ & Sig. \\
\hline \multirow{3}{*}{1} & Regression & 1499.411 & 2 & 749.705 & 123.278 & $.000 \mathrm{a}$ \\
\hline & Residual & 589.899 & 97 & 6.081 & & \\
\hline & Total & 2089.310 & 99 & & & \\
\hline \multicolumn{7}{|c|}{ a. Predictors: (Constant), Harga, Kualitas Pelayanan } \\
\hline \multicolumn{7}{|c|}{ b. Dependent Variable: Kepuasan Pelanggan } \\
\hline & & & & Sumber: Has & ah Data SPS & 22,2018 \\
\hline
\end{tabular}

Berdasarkan tabel di atas, "dapat dilihat bahwa nilai $\mathrm{F}_{\text {hitung }}$ sebesar 123.278 lebih besar dari $\mathrm{F}_{\text {tabel }}$ sebesar $3.09(123.278>3.09)$ dan nilai signifikansi sebesar 0.000 lebih kecil dari 0,05 $(0.000<0.05)$. Kesimpulan yang bisa ditarik yaitu bahwa secara simultan kualitas pelayanan dan harga mempunyai pengaruh positif dan signifikan terhadap kepuasan pelanggan."

\section{Uji Koefisien Determinasi}

\begin{tabular}{|c|c|c|c|c|}
\hline \multicolumn{5}{|c|}{ Tabel 22. Uji Koefisien Determinasi } \\
\hline \multicolumn{5}{|c|}{ Model Summaryb } \\
\hline Model & $\mathbf{R}$ & R Square & $\begin{array}{l}\text { Adjusted } \\
\text { R Square }\end{array}$ & Std. Error of the Estimate \\
\hline 1 & $.847^{\mathrm{a}}$ & .718 & .712 & 2.466 \\
\hline \multicolumn{5}{|c|}{ a. Predictors: (Constant), Harga, Kualitas Pelayanan } \\
\hline \multicolumn{5}{|c|}{ b. Dependent Variable: Kepuasan Pelanggan } \\
\hline \multicolumn{5}{|c|}{ Sumber: Hasil Olah Data SPSS 22, 2018} \\
\hline
\end{tabular}

Menurut tabel tersebut di atas, "bahwa nilai kontribusi (Adjusted $R$ Square) variabel kualitas pelayanan dan harga terhadap kepuasan pelanggan sebesar 0,712. Artinya kualitas pelayanan dan harga memiliki kemampuan menjelaskan variabel kepuasan pelanggan sebesar $71,2 \%$ sedangkan sisanya sebesar $18,8 \%$ dijelaskan oleh" variabel lain di luar penelitian ini.

\section{SIMPULAN}

Pelayanan "mempunyai nilai koefisien regresi sebesar 0.489 , nilait hitung $_{\text {lebih besardarit }}$ tabel $(8.742>$ 1.985) dan nilai signifikan lebih kecil dari 0,05 $(0.000<0,05)$. Artinya $\mathrm{H}_{\mathrm{a}}$ diterima dan $\mathrm{H}_{0}$ ditolak. Menurut estimasi, apabila kualitas pelayanan mengalami peningkatan sebesar 1 satuan maka kepuasan pelanggan akan naik"sebesar 0.516. Hasil analisis menginformasikan bahwa harga mempunyai nilai koefisien regresi sebesar 0.486 , nilai $\mathrm{t}_{\text {hitung }}$ lebih besar dari $\mathrm{t}_{\text {tabel }}(7.342>1.985)$ dan nilai signifikan lebih kecil dari"0,05 $(0.000<$ $0,05)$. Artinya $\mathrm{H}_{\mathrm{a}}$ diterima dan $\mathrm{H}_{0}$ ditolak. Dengan perkiraan apabila harga naik sebesar 1 satuan maka kepuasan pelanggan akan mengalami peningkatan sebesar 0.486 Hasil analisis ini bisa diartikan bahwa kualitas pelayanan dan harga secara simultan mempunyai pengaruh signifikan pada kepuasan pelanggan dengan nilai kontribusi sebesar 0.712, nilai $\mathrm{F}_{\text {hitung }}$ sebesar 123.278>3.09, nilai signifikansi sebesar $0.000<0.05$. Artinya kualitas pelayanan dan harga secara simultan mempunyai kemampuan menjelaskan variabel kepuasan pelanggan sebesar $71,2 \%$ sedangkan sisanya sebesar $18,8 \%$ dijelaskan oleh variabel lain di luar penelitian ini.

\section{DAFTAR PUSTAKA}

Arief, P. (2011). Analisis Pengaruh Kualitas Pelayanan, Harga dan Lokasi Terhadap Keputusan Pembelian Sepeda Motor Honda. Semarang: Jurnal Fakultas Ekonomi Universitas Diponogoro.

Dharmesta, \& Irawan. (2015). Manajemen Pemasaran Modern. Yogyakarta: Liberty Edisi Kedua.

"Haryono, E. W., \& Danang D. (2016). Analisis 
Pengaruh Harga dan Kualitas Layanan Terhadap Kepuasan Pelanggan PT. DMS Tour And Travel. Sekolah Tinggi Manajemen Transportasi: Jurnal Manajemen Bisnis Transportasi Dan Logistik, Vol. 2 No 2 Januari.

Hasibuan, H., \& Malayu S. P. (2014). Manajemen

Dasar. Pengertian dan Masalah. Jakarta: Bumi Aksara.

Januar E. P., \& Ai L. Y. (2016). Pengaruh Kualitas Pelayanan Terhadap Kepuasan Pelanggan Pada JNE Cabang Bandung. Universitas Pelita Harapan: DeReMa Jurnal Manajemen. Vol. 11 No. 2, September; 265-289.

Kencana, P. N. (2017). Pengaruh Produk Dan Harga Terhadap Kepuasan Pelanggan Serta Dampaknya Terhadap Loyalitas Pada Tip Top Supermarket Ciputat. PEKOBIS: Jurnal Pendidikan, Ekonomi, dan Bisnis, 1(4), 5364.

Kotler, P., \& Gary, A. (2014). Prinsip-prinsip
Pemasaran. Jilid 1. Jakarta: Erlangga.

Kotler, P.,\& Gary, A. (2012). Manajemen Pemasaran. Jakarta: Erlangga.

Kurniawan. (2010). Management Marketing. Air Asia: Journal of A Case Study in Air Asia, Hal. 21.

Lupiyoadi, R., \& A. Hamdani. (2016). Manajemen Pemasaran Jasa. Jakarta: Salemba Empat.

Oliver. (2017). Measurement and Evaluation of Satisfaction Processes in Retail Settings. Journal of Retailing. 57(3), 25-48.

Sugiyono. (2012). Metode Penelitian Bisnis. Bandung: Alfabeta.

Swastha, B. (2012). Manajemen Penjualan: Pelaksanaan Penjualan. Yogyakarta: BPFE.

Swastha, B., \& Irawan. (2014). Manajemen Pemasaran Modern Analisis Perilaku Konsumen. Yogyakarta: Liberty.

Tjiptono, F. (2014). Strategi Pemasaran Jasa. Yogyakarta: Andi. 